抗凝固療法中の脊椎手術：

頸椎硬膜外血腫の 1 例とそのピットフォール

\title{
Spinal Surgery during Anticoagulant Therapy : \\ A Case of Spinal Epidural Hematoma and Pitfalls of its Diagnosis and Perioperative Management
}

\author{
村田英俊坂田勝巳岡村泰久保篤彦 \\ 田邊豊菅野洋川原信隆山本勇夫
}

Hidetoshi Murata, M. D., Ph. D., Katsumi Sakata, M. D., Yasushi Okamura, M. D., Atsuhiko Kubo, M. D.,

Yutaka Tanabe, M. D., Ph. D., Hiroshi Kanno, M. D., Ph. D., Nobutaka Kawahara, M. D., Ph. D., Isao Yamamoto, M. D., Ph. D.

\begin{abstract}
A good hemostastatic environment is indispensable in the spinal surgery even when administering a strict anticoagulant therapy. The restoration of coagulant function can be achieved by the discontinuation of the anticoagulant agents and the reversal of anticoagulant status by administering vitamin $\mathrm{K}$ and/or some coagulant factors. However, sudden restoration of the coagulation function may cause a thromboembolic event for those patients who need anticoagulant therapy. The perioperative management of such patients is therefore much more complicated.

A 59-year-old man receiving warfarin as an anticoagulant medication because he suffered from infectious endocarditis, and had had a mitral and aortic valve replacement operation two years ago. A year later, he suffered a cerebral infarction despite his warfarin medication. This time, he had a cervical spinal epidural hematoma beginning with neck pain and left hemiparesis that developed into tetraparesis. The spinal surgery for hematoma removal and laminoplasty was done under anticoaguation reversal. A drainage tube was placed into the epidural space. The anticoagulation with continuous administration of heparin was started 12 hours postoperatively for functional maintenance of his mechanical cardiac valve. His tetraparesis was improving. The drainage tube was removed 48 hours postoperatively. However, spinal rebleeding was encountered three hours after the drain removal, and the patient developed tetraparesis again. An emergency operation was performed. An epidural drain was placed again, and it was removed 12 hours later when the drainage was completed and coagulation function was maintained. The heparinization was restarted six hours after drain removal. Rebleeding did not occur, and the anticoagulant therapy was transferred from heparin injection to warfarin medication. The rehabilitation of motor function was gradually progressed.

Herein, we consider the safest, optimal perioperative management of spinal surgery for the patients taking anticoagulation therapy such as warfarin medication.
\end{abstract}

(Received : October 1, 2008 ; accepted : December 5, 2008)

\section{Key words}

cervical spine, epidural hematoma, anticoagulant therapy 


\section{はじめに}

心疾患や脳虚血性疾患などで十分な抗凝固を要する患 者での脊椎脊髄手術では，術中の良好な止血環境を得る 必要性がある．その一方，周術期の抗凝固抑制に伴う血 栓形成，塞栓症の危険をはらんでいる。周術期は出血と 血栓・塞栓症のジレンマをはらみ，その管理はより複雑 となる。今回，心臓弁置換術後ワーファリン内内服中の 患者が, 頸椎硬膜外血腫を起こし, 手術を行った。術後, 抗凝固療法再開後, 再出血をきたし, 再手術を要した. この症例を通じて抗凝固を要する患者の脊椎脊䯣手術の 管理とそのピットフォールを考察する.

\section{症 例}

\section{患 者：59 歳, 男性}

57 歳時, 感染性心内膜炎にて当院循環器外科で僧帽弁 置換，大動脈弁置換術を行った。人機械弁を使用し， ワーファリン®内服にて PT (INR) 3.0 を目標にコントロー ルされていた．しかし，PT（INR）のコントロール不良 で 58 歳時右側頭葉に脳塞栓による脳梗塞（出血性梗塞） を生じた。急性期に見当識障害，言語障害を生じたが， その後改善し，ほほ後遺症なく元の事務職に復帰してい た。ワーファリンは $6 \mathrm{mg} /$ day で PT（INR）2.6〜3.2 で
コントロールされていた。

今回，誘因なく，早朝，頸部痛で目が覚めた。前日を 含めて外傷の既往はない。 その後左不全片麻痺を生じ， 当院内科受診した。

意識清明, 脳神経障害なし. 左上肢優位の左不全片麻 疩（MMT 上肢 4- $/ 5$, 下肢 $4 / 5$ ), 左前腕，手指にしび れ感（dysesthesia）を認めた。来院時 CT では前回の脳 梗塞のほかは，明らかな低吸収域はなかった。

内科では，昨年の脳塞栓の既往から脳梗塞を考慮し， 入院のうえアルガトロバン $60 \mathrm{mg} / \mathrm{day}$ を持続点滴静注し ていた。点滴開始 3 時間後，急速に四肢麻痺を生じ，呼 吸浅薄となった。緊急で頸椎 MRI を行い，C3-5 レベル 硬膜外に T1 強調画像で等信号，T2 強調画像でやや高信 号の占拠性病変があり，脊髄左側を著明に圧排していた。 硬膜外血腫と思われた（Fig. $1 \mathbf{a} \sim \mathbf{c}$ ). PT（INR）2.73で あったが，抗凝固拮抗療法〔Vitamin K2（Menatetrenone） $20 \mathrm{mg}$ ，新鮮凍結血漿（fresh frozen plasma；FFP） $4 \mathrm{u}$ 投 与」を行い, 入院 8 時間後，緊急手術を行った. C3-5 頸椎硬膜外血腫除去，椎弓形成術を行った（Fig. 1 d, e). 手術所見では，血腫は凝血塊となり，血腫除去後も 出血点は明らかでなかった．止血に難渋することはなく， すべての筋層を温存する形で, hydroxyapatite implant を 用いて椎弓形成術を行った (myoarchitectonic spinolaminoplasty，Fig. 1d，e $)^{1-3)}$. ドレーンを硬膜外に留置し，

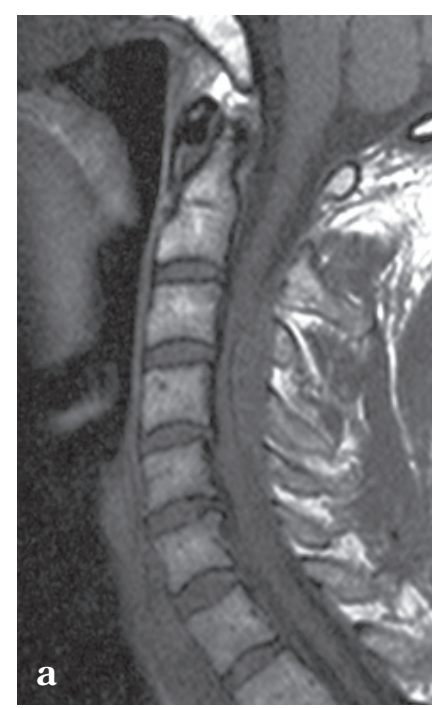

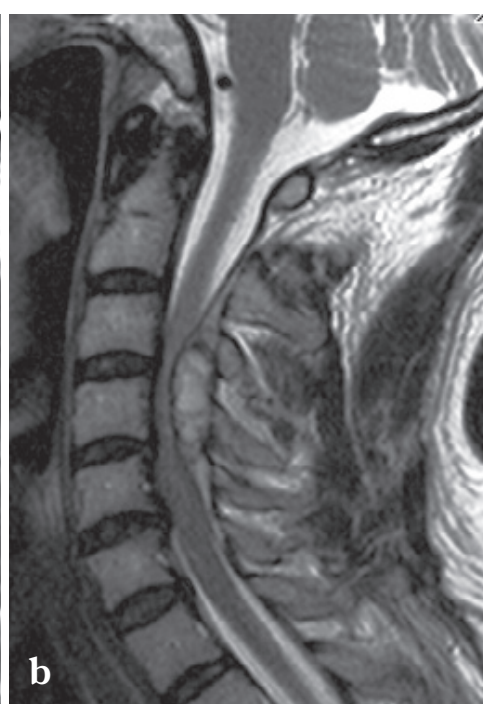
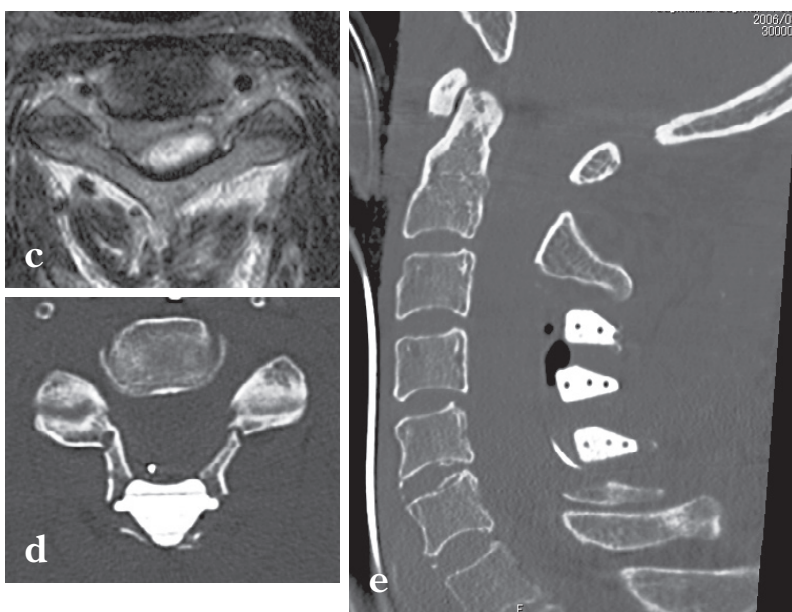

Fig. 1

a - c : cervical spine MRI showed epidural compressive lesion in C3-5, which was a spinal epidural hematoma.

a : T1WI, sagittal. The epidural lesion showed an isointensity signal.

b : T2WI, sagittal. The epidural lesion showed a slightly increased intensity signal.

c : T2WI, axial. The epidural hematoma markedly compressed the left side of the spinal cord.

d, e : CT scans 1 day after the operation.

d : axial image at $\mathrm{C} 4 / 5$.

e : C4-6 laminoplasty is shown in the sagittal image. 


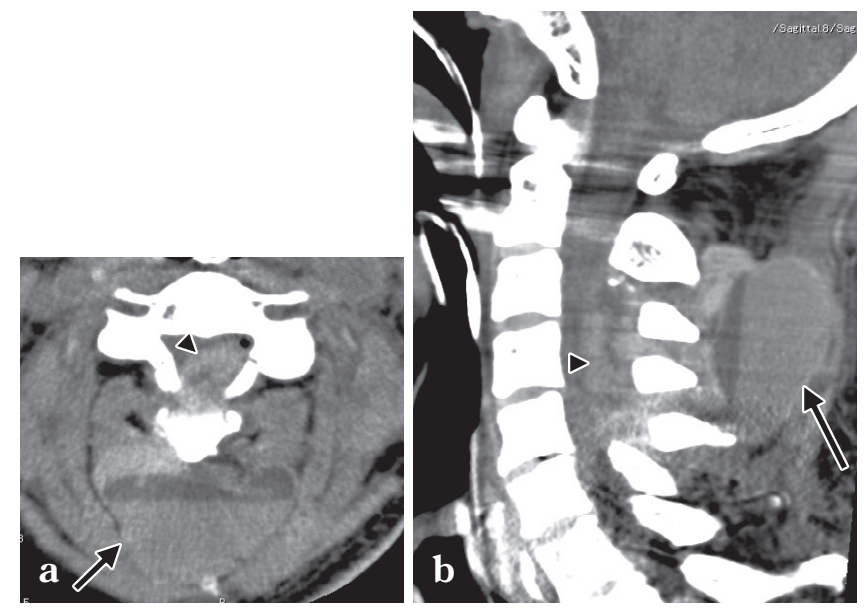

Fig. 2 CT scans after removal of epidural drain A massive hematoma with niveau is shown under the splenius capitis muscle (arrows) developing into the spinal canal (arrow heads).

a : axial.

b : sagittal.

閉創した，術 1 時間後 PT（INR）は 0.91 と正常化して いた，術後速やかに四肢麻痺は改善しつつあった．僧帽 弁，大動脈弁は人工機械弁のため，機械弁の血栓化，塞 栓合併症の危惧があり, 術後 12 時間で抗凝固療法 (へ パリン 12,000 U/day）を再開した. APTT 65〜92 sec で 推移した，術翌日の CT では明らかな再出血はなかった (Fig. 1 d, e). 硬膜外ドレーンからは $40 \mathrm{ml}$ の排液があっ たが, ドレーン血液排出の増加がないことを確認し, 術 後 48 時間でドレーンを抜去した.

しかし, その 90 分後, 再度不全四肢麻疩となり, 緊 急で頸椎 CT を施行した. 筋層内, 筋層下に niveau を伴 う広汎な血腫を認め，再度脊柱管を著明に圧迫していた (Fig. 2)。ヘパリン投与を中止し，緊急で再手術，血腫 除去を行った．手術所見では，すでに出血は停止してお り，凝血していた．出血点は明らかでなかったが，血腫 の㧍もな位置から, 前回ドレーンに接触した筋層（おそ らく頭半棘筋）からの出血と思われた. ドレーンを抜去 した際に出血を誘引し, 抗凝固療法を再開していたため, 広範な出血へと至ったものと推察された。止血は容易で 前回のインプラントをそのまま用い, 椎弓形成をした. 硬膜外に再度ドレーンを留置したが, 前回のような出血 を回避するため, 筋層に接触しないよう項勒带間を通し て皮下より後頸部表面へ誘導, 閉創した。術後 APTT は $48 \mathrm{sec}$ であった．前回のドレーン抜去時の出血の経験か ら，術後，すぐに抗凝固を再開せず，ドレーン排出がほ ぼ停止した 12 時間後, まず, ドレーンを抜去した. APTT
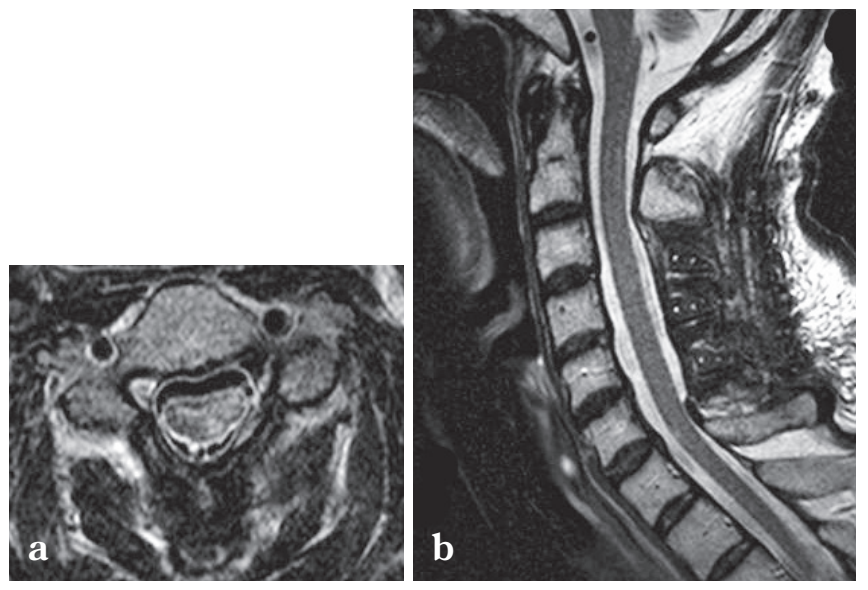

Fig. 3 MRI (T2WI) 35days after operation

The enlargement of the spinal canal and decompression of the spinal cord was achieved. However the spinal cord damage due to previous the epidural hematoma remained mainly in the left side.

a : $\mathrm{C} 5 / 6$ axial.

b : sagittal.

は $39 \mathrm{sec}$ であった．再出血がないことを CT で確認し， 抜去後 6 時間後より抗凝固療法 (ヘパリン $12,000 \mathrm{U} /$ day) を再開した。 その後再出血なく, ワーファリン®内服 $(5.5 \mathrm{mg} /$ day $)$ へ移行した.

四肢運動機能は初回術後より改善は遅れたが, 3 週間 後, 箸での摂食, リハビリテーション室での 4 点杖歩行 が可能となり, 術後 6 週でリハビリテーション病院へと 転院した. 術後 35 日目の MRI では脊柱管は拡大され, 硬膜外血腫に存在したレベルに春髄内の圧迫損傷の変化 を認めた（Fig. 3).

\section{考 察}

春椎硬膜外血腫は, 外傷や脊椎手術術後, 腰椎穿刺後 では多く報告されているが，自然発症例はまれである。 原因として, 血小板機能低下, 凝固能異常を呈する血液 疾患や血管異常が指摘されている ${ }^{4)}$. 一方，抗血小板治

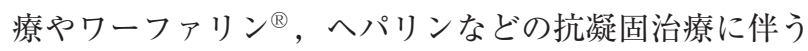
合併症としての医原性出血の報告も少なくない. 自然発 症の脊椎硬膜外血腫の $25 \sim 70 \%$ は抗凝固療法に関連して いるといわれる5).

抗凝固療法中の患者は 2 つの大きな問題点を有する. 原疾患による塞栓由来の虚血性疾患, そして抗凝固療法 に伴う出血性疾患である. 抗凝固療法中の患者が片麻痺 あるいは単麻痺で発症した場合, 頭蓋内出血が否定され るとき, この脳虚血性病変と脊椎出血性病変の瞬時の鑑 
別が難しいことがある ${ }^{6)}$. 必ずしも神経系の専門家が初 診をみるとは限らないが, 頸部痛, 背部痛を伴うとき金 椎出血性病変を鑑別に挙げておくことが重要である.

本例では，僧帽弁，大動脈弁置換術後ワーファリンを 内服していたが, 1 年前に脳塞栓症を発症していた。発 症当初, 左片麻痺を呈していたため, 内科では脳梗塞再 発と考え, アルガトロバンによる抗凝固療法を追加して いた，その後，持続する頸部痛に加え，四肢麻痺へと移 行したため, MRI にて頸椎硬膜外血腫と判明した。発症 当初より頸部痛はあったが, おもに左片麻痺が前景にで ていたため, 脊䯣病変を疑いにくかったかもしれない. 脳梗塞, 脊椎出血どちらも治療的急務を要するが, その 診断によっては正反対の処置となり, かえって病態を増 悪しかねない. 抗凝固療法中の突発的頸部痛, 背部痛は 脊椎硬膜外血腫を鑑別診断として常に考虑すべきである といわれる . 緊急時の診断上のピットフォールと思わ れる.

出血が疑われる場合には抗凝固療法の中断とVitamin $\mathrm{K} 2$ と FFP による凝固機能の是正が不可欠である7). 急 速にワーファリン®の効果を是正する必要がある場合は, 乾燥人血液凝固第 $\mathbb{X}$ 因子複合体製剤 $500 \sim 1000$ 単位投与 も考慮する（『循環器疾患における抗凝固・抗血小板療法

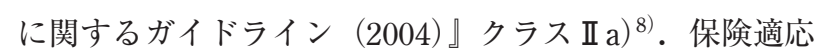
外ではあるが，是正効果は FFP より第X因子複合製剤の ほうがはるかに優れているとされる。

春椎硬膜外血腫の臨床的予後は術前の神経学的重症度 と手術までの時間によって決まるといわれる9). 本例も Vitamin K, FFP を投与し, 速やかに凝固機能を正常に復 しつつ, 血腫除去術, 椎弓形成術を行った. 止血に難渋 することなく操作を終え, 術後速やかに改善傾向がみら れた。

その後僧帽弁置換術後, 機械弁ということで, 早期の 抗凝固療法再開が望まれた。機械弁はワーファリン®に よる厳格な抗凝固療法を必要とする ${ }^{10-12)}$. そして抗凝固 療法を行っていても, とりわけ僧帽弁位機械弁は血栓塞 栓症の発生率が高い. 僧帽弁置換（人工機械弁）術後は, 脳や全身への血栓塞栓のリスクのみならず, 人工機械弁 自体への血栓付着により, 弁機能不全による心不全をき たす可能性がある ${ }^{10-12)}$. 可及的速やかに抗凝固治療を再 開することが望ましい，本例ではドレーン排出がほぼ消 失した術後 12 時間後にヘパリン持続投与 $(12,000 \mathrm{U} / \mathrm{day})$ を開始した。その 2 日後再出血なく, ドレーン排液量は 増加しないため, ドレーンを抜去した。

その後抢そらく筋層からと思われる再出血を生じ, 再 手術に至った。出血素因があるだけに，ドレーン留置は
できるだけ筋層との接触を避け, 皮下と手術進入部のみ を用いるよう, 出血に特に留意した誘導がより望ましい と思われた。

抗凝固療法中の患者の脊椎手術において明確なガイド ラインはな扮確立されてはいない，原疾患のコントロー ルとの兼ね合いで, 術後の頻回な神経学的チェックが唯 一の手立てと報告するものもある ${ }^{13,14)}$.

抗凝固療法中の患者において脊椎麻酔や硬膜外麻酔で の脊椎出血はたびたび報告されている ${ }^{6,15)}$. 通常の脊椎麻 酔での金椎出血の頻度は脊椎麻酔で $1 / 220,000$, 硬膜外 麻酔で $1 / 150,000$ とされる ${ }^{16)}$. 一方, 静脈血栓症予防で の, 低分子ヘパリンの投与でのその頻度は脊椎麻酔で $1 / 40,800$, 硬膜外麻酔で $1 / 3,100$ という報告がある ${ }^{17)}$. これらの出血は穿刺時のみならずカテーテル抜去時にも 起こりうる ${ }^{15)}$. 静脈血栓症予防のための非分画へパリン 皮下注投与自体は, ほかの凝固異常がなければ, 脊椎麻 酔, 硬膜外麻酔の絶対的禁忌とはなっていない. しかし, そのガイドラインでは穿刺前, またはカテーテル抜去の 2〜4 時間前を避け, その処置後 1 時間以上おいて再投与 を行うとされている ${ }^{18,19)}$. すなわち処置の前後にあたっ ては抗凝固作用が消失していることが望ましい.

本例では, 硬膜外ドレーン抜去時, ヘパリンを投与し APTT の延長を維持していたために広範な再出血の主因 となったと思われる.この経験から術後のドレーン抜去 については, ドレーン排出が停止するまでへパリン再開 は行わず, ドレーン抜去後, 出血のないことを CT で確 認して， 6 時間後にヘパリンを再開した. 仮にドレーン を数日留置し, かつへパリンを再開する場合には, ドレー ン抜去前後は凝固機能が延長していないほうが望ましい. すなわち抜去前にヘパリンを中断し, APTT を正常に回 復させ, 抜去を行う. その後数時間再出血がないことを 確認し, ヘパリンの再開が望ましいと思われる. 麻酔科 領域の脊椎・硬膜外麻酔ガイドラインでも同様の方法が 推奨されている18,19).

抗凝固療法中の患者については, 手術開始の際には, 正常な凝固能に回復させることを意識するが, ドレーン 抜去時においても, 同様の留意をすることが肝要と思わ れた。周術期処置上のピットフォールである. 特に本例 のように厳格な抗凝固療法を要する患者ではなおさらで ある。

本症例では, 脳塞栓予防のために抗凝固療法を行って いたが, 脳梗塞のみにとらわれず, 春椎出血性病変を考 慮すること, 手術にあたっては, 凝固機能の回復を促す ことはいうまでもないが, 再出血を誘発しない安全なド レーン留置とともに, ドレーン抜去時など術後処置の際 
も，凝固機能を回復させていたほうが安全である。教訓 的症例として提示した.

\section{結 語}

僧帽弁，大動脈弁置換術後，抗凝固療法中の患者にお ける脊椎硬膜外血腫の 1 例を経験した．本例のように心 臟弁置換後の患者は脳塞栓を起こしやすいが，片麻痺発 症であっても頸部痛を伴うときは抗凝固療法に伴う脊椎 出血性病変を疑うべきである，手術にあたっては，抗凝 固療法を中止し，凝固機能を正常に復することはいうま でもないが，術後，ドレーン抜去などの処置においても， 凝固能を正常に復した状態で処置したほうが安全である.

\section{文 献}

1) Kim P, Murata H, Kurokawa R, et al : Myoarchitectonic spinolaminoplasty : efficacy in reconstituting the cervical musculature and preserving biomechanical function. $J$ Neurosurg Spine 7:293-304, 2007

2）村田英俊，金彪：筋層構築的棘突起椎弓形成術：筋 骨格構造の機能保存と頸部痛の軽減。日脊髄障害医会誌 20 : 100-101，2007

3）村田英俊，金彪：頸椎手術のための外科解剖一筋層 をいかにして温存するか一．顕微鏡下手術のための脳神 経外科解剖XX [第 21 回微小脳神経外科解剖セミナー講 演集]，東京，サイメッド・パブリケーションズ，2008， pp13-21

4) Domenicucci M, Ramieri A, Ciappetta P, et al : Nontraumatic acute spinal subdural hematoma : report of five cases and review of the literature. J Neurosurg $91: 65^{-}$ 73, 1999

5) Kirazli Y, Akkoc Y, Kanyilmaz S: Spinal epidural hematoma associated with oral anticoagulation therapy. Am J Phys Med Rehabil 83:220-223, 2004

6) Pay LL, Chiu JW, Thomas E: Postoperative epidural hematoma or cerebrovascular accident? A dilemma in differential diagnosis. Acta Anaesthesiol Scand 46:217220, 2002

7) Van Schaeybroeck P, Van Calenbergh F, Van De Werf F, et al : Spontaneous spinal epidural hematoma associated with thrombolysis and anticoagulation therapy : report of three cases. Clin Neurol Neurosurg 100:283-287,
1998

8）笠貫 宏，米田正始，他：循環器病の診断と治療に関す るガイドライン（2002-2003 年度合同研究班報告）［タ イジェスト版］一循環器疾患における抗凝固・抗血小板 療法に関するガイドライン. Circulation Journal 68 (Suppl.IV)：1221-1230, 2004

9) Groen RJ, van Alphen HA : Operative treatment of spontaneous spinal epidural hematomas : a study of the factors determining postoperative outcome. Neurosurgery 39：494-508, discussion 508-499, 1996

10) Bayliss A, Faber P, Dunning J, et al : What is the optimal level of anticoagulation in adult patients receiving warfarin following implantation of a mechanical prosthetic mitral valve? Interact Cardiovasc Thorac Surg 6:390396, 2007

11) Koertke H, Minami $K$, Boethig D, et al : INR self-management permits lower anticoagulation levels after mechanical heart valve replacement. Circulation 108 (Suppl 1) : II 75-78, 2003

12) Larson BJ, Zumberg MS, Kitchens CS:A feasibility study of continuing dose-reduced warfarin for invasive procedures in patients with high thromboembolic risk. Chest 127:922-927, 2005

13) Barnes B, Alexander JT, Branch CL, Jr. : Postoperative Level 1 anticoagulation therapy and spinal surgery : practical guidelines for management. Neurosurg Focus 17 : E5, 2004

14) Morse K, Weight M, Molinari R : Extensive postoperative epidural hematoma after full anticoagulation : case report and review of the literature. J Spinal Cord Med 30 : 282-287, 2007

15) Narchi $P:$ Spinal anaesthesia and the use of anticoagulants. Best Pract Res Clin Anaesthesiol $17: 443-449,2003$

16) Tryba $\mathrm{M}:$ [Epidural regional anesthesia and low molecular heparin: Pro]. Anasthesiol Intensivmed Notfallmed Schmerzther 28:179-181, 1993

17) Schroeder DR : Statistics : detecting a rare adverse drug reaction using spontaneous reports. Reg Anesth Pain Med $23:$ 183-189, 1998

18) Horlocker TT, Heit JA : Low molecular weight heparin : biochemistry, pharmacology, perioperative prophylaxis regimens, and guidelines for regional anesthetic management. Anesth Analg 85 : 874-885, 1997

19) Liu SS, Mulroy MF : Neuraxial anesthesia and analgesia in the presence of standard heparin. Reg Anesth Pain Med 23: 157-163, 1998 